\title{
GLIMPSES OF ARMY LIFE FROM WITHIN FROM 1860 TO 1895
}

\author{
WILLIAM MORRISON, J.P. \\ Honorary Captain and Quartermaster, Army Medical Service \\ (Lieutenant of Orderlies 1879-1881)
}

(Continued)

On the 8th January 1880 I reported myself at Aldershot for duty in the Depot pending the recovery of the Quartermaster from an attack of enteric fever. I was not long in the office when I saw that the real Commanding Officer was the Sergeant Major. He withdrew one of my clerks without giving me the least warning. I ordered the man back to his work and dared the Sergeant Major to repeat the offence or to interfere in anything that concerned my duties. Next morning was summoned to the Orderly Room and questioned by the nominal commanding officer-Surgeon Moore as to my reason for liberating ten men from the Guard Room after being confined there for being ten minutes late at tattoo. I informed him that the custom in my regiment was to send absentees, who were in barracks before "lights out" to their rooms to appear at the Orderly Room next morning, and that as Orderly Officer I was within my rights according to the usages of the Service. I was never again detailed for duty as Orderly Officer in the Depot.

Early in March 1880 I was posted to the 3rd Station Hospital, North Camp for duty. Here I had to contend with an under-current of opposition from the Senior Medical Officer (Surgeon Major Wade). I resented this and asked for an explanation. He told me that he wanted no officer of my rank, as the samples he had had there were such as to prevent him from countenancing another. I suggested that he should withhold his judgement until I was for some time subject to his orders.

I told him that the conduct of certain officers who visited 6 Whitehall Yard from Aldershot and complained of the influence exercised over the Principal Medical Officer by Lieutenant Mullins was not creditable to officers who ought to be gentlemen. He saw that I knew more than he cared for me to know and ceased his veiled opposition. I was determined to assert my place in the Hospital at whatever cost. I saw that both patients and orderlies were being defrauded, the former by the hospital cook, and latter by the wardmaster. I watched the cookhouse closely for several days and about eleven o'clock each morning saw a female belonging to the Corps crossing the Prison Warder's Quarters. I was soon satisfied of the nature of her visit and on the following day waited until the meat was in the oven, then entered the cookhouse and examined drawers, cupboards and corners. Concealed under the dresser, wrapped in a cook's apron, was twenty pounds of rump beef ready to be transported elsewhere as soon as I left the neighbourhood of the cookhouse. I placed the cook in arrest and marched him over to the Orderly Room. The Senior Medical Officer denounced my interference and insisted that I withdraw the charge. His reason was to avoid the publicity of a Court Martial for theft and the consequent disgrace to the Department. I told him that I would apply for the man's immediate removal and give my reason for doing so. He then gave him five days confinement to barracks and altered the crime to read " irregular conduct in the cookhouse". On the following day I went to the Director-General's Office and within the week the 
man was on his way to one of the Mediterranean stations. Having got rid of one of the pilferers I next turned my attention to the Colour Sergeant's grocery account for the Army Hospital Corps. The man by sleight of hand appropriated one shilling a day from the Mess Book by an arrangement with the grocer. It was done so neatly as to defy evidence that could convict on a Court Martial. As his period of service had expired I suggested that he should apply for his discharge, which accordingly he did. On leaving he informed me that the Senior Medical Officer had given him instructions to thwart me as far as he could in carrying on the work of the Hospital.

The drunkenness of the non-commissioned officers was appalling. A roll call at Tattoo was one of the vestiges of the old discipline left to the Establishment. As the Orderly Officer never attended, it was taken for granted that it was but a relic of the old dispensation that could be violated with impunity. One night I attended the parade unexpectedly. I arrested one sergeant, three corporals and one lance-corporal. The sergeant and two corporals were tried by Court Martial and reduced. This cured the chronic state of alcoholism from which the Detachment suffered. The Senior Medical Officer * determined to make my position as onerous as he could make it without bringing himself under discipline. He informed me that he would not tolerate my interference with the men nor with the discipline of the wards.

I pointed out to him the Regulations regulating my duty, and that I would carry out these whatever his views were. I brought an orderly before him charged with leaving the hospital improperly dressed. He sentenced this man to seven days with hard labour: When the office was cleared I pointed out the severity of the punishment and suggested consideration. He declined to interfere with the sentence and began to rail at the unnatural edict that transformed him from a doctor into a Provost Marshal.

Shortly afterwards, the Senior Medical Officer and another member of the executive staff happened to be posted, one to Portsmouth the other to Preston-a posting in no way connected with that recent case. On the arrival of Surgeon Major Nash as Senior Medical Officer I had the full control of discipline and internal economy laid down for me by the Regulations of the Corps. It was a pleasure to serve under this officer. Gentle and genial in his manner and bearing, conciliatory in his administration, he endeared himself to the Hospital subordinates in a very short space of time. I soon had a well conducted hospital and with generous pecuniary assistance from the Medical Officers organized a football and a cricket club, with such success that in the following seven months only three crimes were registered with the detachment numbering thirtysix non-commissioned officers and men. Four of these men have since been commissioned into the Royal Army Medical Corps. On visiting the Depot a short time before leaving the Camp, I was asked by the Commanding Officer what magnetic influence drew the recruits, who had just finished their training at the Depot, to the 3rd Station Hospital? He had no applications for transfer to the other Hospitals in the Camp. I enumerated a few of the attractions - butter every day for breakfast and tea, plum pudding alternately

\footnotetext{
* Note entered later on in the Autobiography: On reporting from the West Indies in November 1886, at the Director-General's Office, I was told by the Director-General, Sir Thomas Crawford, that this officer had sent him an urgent message asking that on landing I should be sent to Chatham, where he was Senior Medical Officer. Sir Thomas remarked that as this was the first application he had had for a particular officer by name in our Corps, he would like to oblige him, adding" Devonport needs you very much, but evidently you served with this officer before.". I declined to respond to my friend's appeal, His appreciation came too late.
} 
with rice pudding for dinner, cricket and football after four o'clock for every man off duty, strict discipline without crime, and instruction in dispensing medicines for such as wished to qualify as compounders. This made up the happy family at North Camp Hospital.

While serving in the North Camp I was asked by Lady Hope Grant to superintend the work of the Soldiers Home, disburse her charities and to keep in touch with her work among the women of the Garrison. She was very much interested in the sewing meeting and general spiritual work carried out by the Reverend Jabez Parkyn, the acting Wesleyan Chaplain at the North Camp.

I remarked one day to her that it came rather hard on Mr. Parkyn to have to go to London to purchase calico and other necessities, having to lay out his money until the sale of the finished articles. To this she informed me that she allowed Mr. Parkyn twenty pounds sterling per annum, paid through the Reverend R. W. Allen, to pay for this outlay. I then told her that he never got a penny of it, and asked her if she contributed to the Home Mission Fund of the Wesleyan Methodist Church. She replied that she did not. I then informed her that I saw her name in that List for twenty pounds. She was indignant at the liberty Mr. Allen had taken with her generosity in giving what should have been paid to Mr. Parkyn to a connexial fund. She at once summoned $\mathrm{Mr}$. Allen to meet her the following morning at Major Knollys, R.A., then Brigade Major at Aldershot. Lady Grant declined to take the same view of the transaction as did Mr. Allen, and I know that the Major lost faith in the doctrine of entire sanctification from the conduct of its expositors. For this unconscious exposure of Mr. Allen's zeal for the Home Mission Fund at the expense of another, I was never forgiven, and whatever service I rendered to the Church was valueless in his eyes ever afterwards. After having mastered every Polity of Methodism I had known to have passed through the Press, from Grinrod to Williams, I suppose he adjudged me too combative to exercise any influence in Connexial Committees, so I was never given the opportunity to serve on such.

While attached to the 3rd Station Hospital, a case of some public interest came before the Police Court in the spring of 1880. A Sergeant of the Army Hospital Corps, who had formerly been a Regimental Sergeant was in charge of the Medical Stores at the Camp, under the supervision of the Lieutenant of Orderlies attached to the Cambridge Hospital: On assuming charge this sergeant found quantities of Medicines, Surgical Instruments and Appliances surplus in store. This accumulation came from the Regimental Hospitals on their abolition and the introduction of Station Hospitals. Apparently the stores thus collected were never taken on charge by the Apothecary to. the Forces, who had the charge of the stores when the unification scheme was practically adopted,

This culpable neglect of duty was shared by the Apothecary who was then in charge of the supply of medicines at 6 Whitehall Yard, and who should have called for a Return of all the stores returned on the closure of the Regimental Hospitals. When Lieutenant of Orderlies Mullins took over charge of the stores the Ledgers were in perfect accord with the stores as certified by a Board of Medical Officers, over forty cases were in the cellar under the room floor.

It subsequently transpired that the sergeant had covered the trapdoor with medicine chests, panniers etc., confident that he and a confederate alone knew of the existence of the cellar. When they attempted to move all these stores secretly, a woman, who was in 
the secret, gave information to the Police that led to the arrest of the sergeant and his friend. After several remands, the sergeant was committed to the Winchester Assizes, while his friend against whom no charge could be made, or at least sustained, except guilty knowledge was discharged from custody. His acquittal could not save him from the ire of 6 Whitehall Yard, who refused to sanction his re-engagement on completion of his limited engagement.

Before the cases had been unearthed, Lieutenant Mullins had left the District for duty in Sheffield. There was much adverse criticism in the Press about the system of dealing with Army Medical Stores. Higher authority sought to make Lieutenant Mullins the scapegoat for the inefficiency of his predecessors in office. He was recalled from his station to appear before a Court of Enquiry, convened to ascertain the possibility of so much stores being there unaccounted for unknown to the officer in charge. I had reason to know there was a strong determination at Headquarters that Whitehall must be whitewashed by the punishment of Mullins. It was of little consequence to them what happened to a Lieutenant of Orderlies.

I waited on the acting Principal Medical Officer, Deputy Surgeon General Herbert Reade, V.C. and explained to him how the cases in question were hid, offering to give advice to the Court of Enquiry, also emphasizing the fact that the medical officers who transferred the-stores to him on the assumption of his charge were responsible for the accuracy of the quantities expended and remaining, and not on the officer receiving the stores. I then explained the existence of the cellar under the store. The Royal Engineer Department denied its existence.

Having stored my empty bottles and packing cases in the same cellar in 1872 I was sure of its existence. Accompanied by three officers and a representative of the Royal Engineers Department, we visited the stores and on the removal of medicine chests exposed the trapdoor to view. The absence of a trapdoor outside other huts appropriated as canteens had led the Royal Engineers to deny its existence. Whitehall Yard was vanquished,

The Army Medical Department in 1880 had entered on a new lease of life. Seventy young men of superior professional attainments had just entered the Service. They were enamoured by the promise of combatant rank and disciplinary control of the Hospital Staff looming in the distance. If there is any virtue in combatant rank, they have surely a higher claim to it than to any other of the Departmental Services, if perilous and unselfish service count for reward and appreciation in the public estimation. They are in the thick of the fight and the last to leave the field. They are in the centre of, disease by night and day.

It was a pity that in attaining combatant rank for themselves, it was considered desirable to take the combatant rank away from the commissioned officers of the Army Hospital Corps, who were to become in their new commissions " only Honorary".

(W.K.M. It is appropriate now, 10th February 1973, to look at his Commission-

To our trusted and beloved William Morrison, Gentleman ... to be an officer in the Medical Department of our Army . . . in the Rank of Lieutenant of Orderlies in our Army Hospital Corps ...

William Morrison, Gent, Eleventh day of December 1879 Lieutenant of Orderlies. in the forty third year of Our Reign VICTORIA Reg.) 
The unsettled state of South Africa towards the close of 1880 led to the removal of two Army Hospital Corps officers from Netley Hospital, the senior Captain Ward to South Africa, the other to Pembroke Dock. When the news of Captain Ward's removal to South Africa was noised throughout the Establishment, a wail of general disapproval was heard in every direction. Those who relied on him to do all their work were much perturbed, while those who set all regulations at nought were ready to enter a protest against his removal. If Captain Ward was removed the heavens would fall and Netley would disappear in the general confusion. To replace such a colossus would be difficult was the general feeling in Netley. Captain Ward himself had no such feeling. It was going to be difficult to succeed him, but I was assured by Whitehall Yard of their support of my future conduct in the exercise of my duties there.

Shortly after my arrival the sergeant cook took his discharge from the Service rather than jeopardise what he had already acquired. I was informed that the Commissariat Staff never examined the diet sheets at Netley. Of this I was soon painfully aware. Had the Commissariat done their duty, mine would have been of a less disagreeable nature. I stopped unauthorized extras and reported defaulting medical officers to the Divisional Superintendents, better known as Assistant Professors. It took a long time to rectify matters, but a little trouble put matters right eventually. (W.K.M. The Commandant of the Royal Victoria Hospital, Netley was a combatant officer Sir Charles Knight Pearson, K.C.B.).

At the end of the first month a document was submitted to me for my signature, in which it was shown that the articles enumerated thereon were used in cleaning hospital wards, kitchen, surgery and stores. I demurred at the excessive expenditure and declined to sign it until I knew more about it. I was then informed that since the opening of the Institution every accessory connected with the Establishment, Police, Canteen, Schools, Civil contractors all drew their cleaning materials from the hospital stores. I ordered this practice to be discontinued at once. I had unwittingly trodden on a hedgehog. For eighteen years Netley Hospital had revelled in "Home Rule". Everyone had what he wanted without question, provided it was to be found in the stores. (W.K.M. I am reminded of a very fine C.O. in a Hospital in Basra, who used to say to his officers "If you want "white" for your tennis courts you will buy it in the bazaar, and if you can't get it there, then you can have it out of the hospital stores.") The howl reached the Commandant's Office and I was summoned there to answer for my conduct.

The Commandant Sir Charles Pearson stormed at my withholding soap and cleaning articles from the school, garrison church and discharge depot without referring the matter to him. I repudiated his prerogative to interfere in matters affecting the conduct of my stores, and told him if he had any reason to complain to do so through the Principal Medical Officer. Aesop's frog could hardly have swollen to the dimensions of the little man. I was told that he was supreme in the Establishment and I must forthwith issue the stores. I told him that if he gave me a written order that I would issue the articles, but no order written or otherwise would ever make me sign the War Office return that would imply that the stores had been used for Hospital purposes. I pointed out to him I could not produce a verbal order as a supporting voucher to my accounts. He immediately interviewed the Principal Medical Officer and amplified his: grievance. I was sharply denounced for my perversity and ordered to make the necessary issues. I offered to issue the cleaning materials under protest but would not sign the Return 
and would immediately appeal to the War Office. The Principal Medical Officer called the Senior Commissariat Officer to his aid, who cooly informed me that my predecessors had signed the certificate in question for many years and were never called to task for doing so. I suggested that I should submit two forms, one for me to sign and the other he could sign. He declined to do this. The matter was referred to the War Office, when my action was approved of and provision made by a special War Office circular for schools and churches. It is at times unfortunate to be on the winning side. I found that there are species of humanity that will not brook a rebuff. I was led to understand that I . would pay for my victory, and cautioned to walk warily over the slippery pavement on which I had chosen to walk.

In a few days a complaint reached the Principal Medical Officer, that I had neglected to issue plain clothes to invalids, and greatcoats and accessories to men leaving for various destinations. This was no part of my duty. It was the duty of the Assistant Commandant, who found it irksome to discharge any duty outside his office and who thought that an occasional theatre ticket thrown at the officer of orderlies would amply recompense him for such menial work as fell to the lot of the Staff Captain yclept Assistant Commandant. As theatre going was not among my failings, I felt under no obligation to add this burden to my multifarious duties and declined to add this extra work to my own duties.

My refusal was referred to the General-Officer-Commanding the Southern District, Prince Edward of Saze-Weimar, who very peremptorily ordered my compliance with the Commandant's instructions. He had before him one side of the question and I determined that he should soon have the other side. I accepted the duties and appealed to the Field-Marshal, Commanding-in-Chief through the Director-General Army Medical Department. His Royal Highness called on Prince Edward to cancel his instructions delegating me to carry out the Staff Captain's duties, and if the Staff Captain was not equal to carrying out his legitimate duties he should be placed on half-pay.

The Commandant again appealed to Prince Edward to compel me to undertake this duty of the Staff Captain. Colonel Bray, then Assistant Adjutant-General wrote to the Commandant as follows:- "I am directed by His Serene Highness to requote Horse Guards letter on this subject and to request that you will not impose again on the Lieutenant of Orderlies duties outside his legitimate work." Henceforth I was to be crushed if the opportunity offered.

My previous experience in almost every branch of work in the hospital gave me unusual facilities in carrying out my work which would take a stranger years to acquire. This gave me a certain degree of independence.

A few weeks before the departure of Captain Ward for South Africa it was arranged that the Detachment Army Hospital Corps should be formed into two companies, one to be commanded by the Assistant Professor in charge of the Medical Division and the other to be commanded by the Assistant Professor of the surgical Division. The application of the Army Discipline Act was new to them and led to occasional doubtful decisions, whereupon the men would come to me for advice and help. This did not make relations with these medical officers easy, particularly when their decisions on some of the cases had to be reversed.

On making my quarterly inspection of stores, I found a surplus of ten tons of coal 
in the coal store, the accumulation of some months. I at once took it on charge as "found surplus on stocktaking ". When this reached the Commissariat Office the news soon oozed out to the outer world and various enquiries were made as to the correctness of the report. The Mess President called at my office to know if it was true. I confirmed the report by producing the ledger. He then informed me that my predecessors had always given the Officers' Mess whatever was surplus on stocktaking and sneeringly asked what thanks I expected for the innovation. I informed him that I was not working for thanks, but for the righteous discharge of delegated duties. His commentary was neither edifying nor parliamentary. On the breaking up of the medical school a few days after our interview, he retaliated by striking my name off the list of invited guests to the lunch, a courtesy always, until then, extended to Honorary Members. This harmonizes with the invariable courtesy shewn by medical officers towards officers of their own Department who have had the misfortune to be commissioned from the ranks.

Early in 1881 an order from the War Office directed the Principal medical Officer to prepare a draft of thirty-five men to be in immediate readiness for embarkation to South Africa. This duty devolved on the District Officer by the Regulations of the Corps, subject to the approval of the Principal Medical Officer. Fearing to offend the officers commanding the companies, the District Officer hesitated to make the selection on his own responsibility. His peace-loving disposition dreaded the ordeal.

The District Officer, Captain of Orderlies Thompson, came into my office with the order in his hand undetermined on his course of action. I pointed out to him that the Regulations of the Corps imposed that duty on him and that he should allow no other to interfere in it, and suggested that he should select the best men in the Detachment beginning with the first arrivals at the Station until he had the required number. This was accordingly done and the roll submitted to the Principal Medical Officer, and inserted in Corps Orders. The wasps' nest was stirred and a buzz of angry tongues vied with one another in decrying the outrageous order that was to deprive them of mess waiters, servants, clerks and storekeepers.

Those thirty-five men were regarded as fixtures at the station, and it was supposed that if they were removed matters would inevitably come to a standstill at Netley. The Principal Medical Officer, Surgeon General David Reid Mackinnon, wavered in the matter but felt disposed to carry out the Captain of Orderlies' detail, the selection being in the interests of the Service. Brigade Surgeon Veale was loud in his protest and insisted that the Regulations of the Corps should be set aside and that Officers Commanding Companies should make the selection and not the District Officer, and carried away by his own eloquence shouted it was not the Captain of Orderlies but the Lieutenant of Orderlies who suggested this outrageous interference.

This put another complexion on the matter. In vain the District Officer protested that he and he alone was responsible for the detail. The detail was cancelled and others hastily collected and sent off to Aldershot for duty in the campaign. I protested at this. selection but my protest was also unavailing and this collection was dispatched with all haste to Aldershot. On the day on which they embarked for South Africa I accompanied Captain Thompson to Southampton to witness the embarkation. When the Aldershot contingent reached the docks, they presented the appearance of having been too familiar with the Railway drinking bars between Aldershot and Southampton. I suggested to the officer in charge of the Detachment to place an armed sentry on each gangway 
before dismissing the men. This he neglected to do, and in five minutes, twenty-five of their number bolted into the worst dens in Southampton. Captain Thompson and $\mathbf{I}$ started in pursuit and within the hour, without policemen or other help I brought fifteen of their number back to the ship. Being in uniform I was not interfered with being regarded as one of the higher ranks of the Municipal force authorized on some occasions to burst open a door. Captain Thompson returned with another bevy, while the stragglers were run to earth by the local police before the ship left the docks.

Among the men sent out in this draft was a man of the Corps in the Discharge Depot Cookhouse. When his removal was reported to the Commandant I was sent for to his office and in his usual bullying style asked by whose authority I removed Private Maxwell. I replied by the authority of the Director-General of the Army Medical Department. Livid with rage he roared " D . . you, D . . the Director-General, D . . . the whole lot of you."I saluted him and walked out. I went to the office and wrote a report of my interview and gave it to the Principal Medical Officer for transmission to the Director- General, he subsequently led me to believe that he had forwarded it, but it was still in his desk when he left the Service.

A few days after this outburst I was summoned to the Commandant's office and was asked by what authority orderlies of the Army Hospital Corps were employed at the opening of each session to act as servants to the Medical candidates under instruction at the Army Medical School. He had for some time been manoeuvring to get a company of infantry to Netley for reasons of his own. I informed him that the men were in excess of the Nursing Establishment and that between the school sessions I employed them on the grounds. That one man had to serve four cadets, receiving fourpence a day for his services. He remarked that everyone he asked gave him that information, but what he wanted was the War Office Authority and no one in the building could give him that information. I suggested that a search for the War Office file of letters for October 1863 should be made and that some where about that period the document in question would be found. I informed him that I had been employed in the Purveyor's Department of the Army Hospital Corps at Netley from July 1863 to January 1864, and that the authority must have passed through my hands. After two days exhumation of antiquated documents the letter was resurrected and as the warrant officer in charge remarked "the searchers have blessed you backwards for your knowledge of the ancient history of Netley." The Commandant's demeanour softened towards me after that incident.

I was now settling down to a firmer grip of my work and felt that if $I$ was to be blamed for whatever went wrong in my portion of the Establishment, I must have a free hand. Accordingly I determined to follow the Regulations of the Corps in their entirety. One morning while visiting the gardeners I found that they had been removed from their work, to which I had assigned them, and had been transferred to the Officers' Tennis Ground and Gardens. I removed them at once and forbade them leaving the work I had assigned them. An hour after I was summoned by the Principal Medical Officer and railed at for removing the gardeners. I was told that he had given the gardeners into Dr. Dobson's charge and that I was on no occasion to interfere with them. I told him that I thought he knew me now sufficiently well to know that I would not allow Dr. Dobson or any other to encroach on my prerogative, and seizing the Army Hospital Regulations off his table, pointed out to him that the gardeners and the hospital grounds were in my charge and turning to Dr. Dobson, at whose instigation I was sent for, 
remarked that if the officers had grounds and gardens they must find a gardener, but they could not have the hospital gardeners. To this the Principal Medical Officer remarked "I suppose I must let you have your own way or you will appeal to your friend Munro", to this I replied "Most assuredly". "Weel, Weel, I had better let you have your own way than be told by that bodie Munro to do so". He had a horror of hearing any reference to Surgeon General Munro who was his bete noire.

Shortly after this I had a visit from Surgeon General Longmore and Surgeon Major Hogg who complained that certain medical candidates were neglecting their studies and that I must take them into quarters in the hospital. I repudiated any responsibility for the medical candidates, that when I found them quarters, lodgings in the village, I had no more to do with them until I took the quarters from them on leaving the station. The medical school must deal with breaches of discipline. I was then informed that certain young ladies frequented the house each evening and interfered with the young men's studies, and that I must inform the lady who provided the lodgings that if these ladies persisted in visiting the house the young men must be removed. I called on the lady and delivered my message and interviewed the candidates, who resented the interference in no measured terms, implying that if they were "lambkins" they were not kids and suggested that I should put the old foggeys who sent me into the confessional box to recite the story of their student days. I told them that the confessional box was not an institutional of my country, but I was under the impression that the "cuttie stool "would be more in their line than the confessional. I had carried out my instructions and left the medical school to deal with the matter. Next morning I was favoured with an interview from the mother of the young ladies demanding an apology, failing which she would leave her solicitor to deal with the matter. I referred her to Surgeon General Longmore for enlightenment. I heard no more of the matter.

I had reason to doubt the integrity of the corporal in charge of the linen store, and determined to justify my suspicions or, his uprightness. At each inspection of the linen stores he had always an excuse for his unpreparedness to have his stores counted, pleading for delay until he had obtained the customary receipt from the laundry for soiled linen sent there. I agreed to the postponement on three successive inspections but suspecting something was wrong, I decided to oust him. Having found on the fourth occasion everything correct, I took possession of the keys. In vain he pleaded for two hours in which to put his stores straight and put his personal kit out. I felt sure that he was deficient of certain articles which he borrowed on those occasions either from the commissariat sergeant or from the superintendent of the laundry in order to tide over his inspections. Three days after he had been replaced by another non-commissioned officer, I had a request from the laundry superintendent to return the linen and clothing she had given the storekeeper for his inspection. Having thus obtained the information I wanted I called on Captain March, the Commissariat Officer and made a charge against the Laundry Superintendent of assisting one of my subordinates to rob me. Captain Marsh called at the laundry, when the Matron acknowledged that this had been going on, like many other irregularities from the first year after the Establishment was open, each non-commissioned officer in charge of the Linen Stores passing the system on to one another. She had to pay a heavy bill for the deficiencies and went very near to losing her appointment. The corporal's promotion was blocked.

The Hospital was by this time November 1881 reduced in numbers and the winter's 
hue was settling down everywhere. Officers were packing up for general leave, among them the Principal Medical Officer.

Three or four days before he left Deputy Surgeon General Dickenson of the Indian Medical Service called upon the Principal Medical Officer with a request that his brotherin-law Major Godson of the Madras Army might be received into hospital for treatment on his arrival in the Southampton water from India. This officer was invalided from Afghanistan suffering from wounds and dysentery. Professor Maclean being a brother officer of Dr. Dickenson's it was expected that he would interest himself in the case. The Principal Medical Officer, Professor Maclean and Dr. Hogg met in private and decided to refuse admission to this officer on the plea that the officers quarters burnt out eighteen months previously had not been restored. They thought the responsibility rested on the Royal Engineers and that refusal would expedite the restoration. On calling at the office during the afternoon, the Chief Clerk, Sergeant Major Phillips informed me of the refusal, and suggested that I should make an effort to persuade the Principal Medical Officer to reconsider his decision. Accordingly, I waited upon him and asked whether a sick officer was to be admitted for treatment or not in the course of a day or two. He replied that an application had been made by a relative of a sick officer, but that he had refused it, and that until the Quarters were repaired no more sick would be received. I reminded him that I had nursed sick officers in the building before the Sick Officers Quarters were ever thought of, and that I was prepared on twenty-four hours notice to accommodate fifty sick officers if the necessity arose, adding that the object of throwing blame on the Royal Engineers appeared injudicious.

I told him that we could put every medical candidate in the building on the lodging list if accommodation was required for sick officers. He thought the commissariat officer would not allow this. I replied I would not consult him but inform him after the arrangements had been made to receive the sick officers. I further added that this refusal might lead to a question in the House of Commons on the assembly of Parliament, which would not rebound to the credit of the Department. I was requested to drop the subject. I at once left him. In the corridor I met Mrs. Deeble, the Superintendent of Nurses to whom I related Surgeon General David Reid MacKinnon's action. She was indignant at the refusal and begged that I should return to him and explain the disgrace it would bring on the Hospital if the refusal reached the Public Press. Mrs. Deeble added that if any trouble should arise over it, " It is you and I who would get the blame for unpreparedness, not him ". I returned to the office and had another interview with him, and gave Mrs. Deeble's message. I was requested to mind my own business and to tell Mrs. Deeble to do the same. Nettled at the rebuff and his blind persistency, I replied that it was my business to have quarters to receive the sick, and that it was Mrs. Deeble's business to have the sick nursed as soon as they were in quarters, and that both were ready if he required our services. I thanked him for his courtesy in granting the interview and withdrew in disgust.

On returning to London, Deputy Surgeon General Dickenson wrote a letter to "The Times" newspaper telling the story of the refusal to admit his wounded brotherin-law into the Royal Victoria Hospital at Netley, and the lame reasons given for the refusal. Major Godson, the brother-in-law; was removed by rail to London and died a few days after reaching home. The Horse Guards, I believe, on the personal appeal of Queen Victoria, called on the Director-General for an explanation for the refusal 
to admit a sick and wounded officer returning from active service. The Director-General, Sir William Muir, K.C.B., called for a full report from the Principal Medical Officer at Netley.

Brigade Surgeon Veale was acting Principal Medical Officer during the absence of his chief. I was summoned to the office to answer the charge of inability to accommodate one sick officer, naturally putting the blame on me. I explained the whole case to Dr. Veale, offering to give him a written statement. Looking up from his desk, he asked "do you expect me to tell all this to the Director-General". I replied most certainly and if you do not, I shall give it to you in writing to save myself. Dr. Veale satisfied himself with writing that the Surgeon General, who refused the application was on leave and that on his return a Report would be made to the office. He returned in March but not in a amiable mood. On the previous week Surgeon General Longmore had been awarded the Distinguished Service Reward of $£ 100$ per annum. This was gall and wormwood to our Principal Medical Officer, feeling that he had been punished for the free expression of his opinion of the Depot Army Hospital Corps at Aldershot. I was sent for to the office to give a resume of events in the life of the Establishment since his departure. His first question was " Have you heard that "Gunshot" has been given the Good Service Pension ?" I replied in the affirmative. "What did he get it for?" "For minding his own business and for his services to humanity". This did not please him and drawing a letter from his breast pocket, he remarked "I am sending this letter to the chief clerk in the Director-General's office to give him my opinion of the DirectorGeneral ". He then read the letter. I asked him if he had anything to lose by keeping quiet. He had, he said, been passed over for his pension and that he had now lost hope. I suggested that he should put the letter in the fire and thank his stars when he saw the letter in flames. I told him that I knew Mr. Clarke better than he did, and I knew what he would do when that letter reached him. He was in no mood to accept my advice.

When I left the office he read the letter to one of the consultants, who applauded his independence and advised him to send it on. Towards evening he called his chief. clerk, Sergeant-Major Phillips into his sanctum and gave him the precious letter to read. The Sergeant-Major begged him to put it in the fire, but all to no purpose. The missive was dispatched.

On the third morning I was with him in the office when the clerk handed him a letter. I was prepared for this. I saw his face assume in turn, every colour of the rainbow. I felt sorrow for him. It was couched in Sir William Muir's best scalping style. After he read it he handed it over to me to peruse. I saw what he had injudiciously brought on himself. The first sentence was the communication of the displeasure of His Royal Highness, the Field Marshal Commanding-in-Chief at the gross inhumanity he had exhibited in refusing to admit the late Major Godson into the hospital. The next sentence expressed his own displeasure at his want of administrative capacity in not turning out the Medical Candidates on to the lodging list when quarters were required for sick officers, and the third regret for having cause to censure an officer of his age and experience.

This letter completely upset him and he appealed to me for advice. I suggested that he should apply for leave pending retirement in the early days of May and say no more about Major Godson's case, and clear out of the place. He remarked that he had had all the leave to which he was entitled for the year. I quieted him on that point 
telling him that his leave would be granted and a successor appointed. The leave was applied for and granted, and Brigade Surgeon Rowbotham was ordered to Netley as acting Principal Medical Officer. Again he took counsel of Ahithophel (W.K.M. See Page 185 of the July 1974 issue) cancelled his leave and determined to justify his conduct with regard to the late Major Godson's case seeking to transfer the blame from himself to Dr. Hogg and Professor MacLean. The Director-General refused to accept any justification, or withdraw the censure, and ordered him to quit his quarters on the day on which he attained his 60 th birthday. This request galled him more than the censure. The newly appointed Acting Principal Medical Officer was junior in relative rank to the Commandant. The Commandant attempted to "boss" the show but failed in the attempt. He met with an officer his superior in administrative ability, as in tact, and conscious of this would not allow his natural inclination to hasten him on to a fall.

The arrival of a draft of invalids numbering over seven hundred gave him an opportunity to extend his feelers. He arrived at the station to see the men detrain and taken over by me from the officer in charge. I marched them to hospital, and when opposite the Officers' Mess I sent a non-commissioned officer to acquaint Dr. Ash, who was in the tennis courts, to come to the hospital at once in the dress in which he was playing. The Commandant walked down with me and heard the message to Dr. Ash. On arrival at the hospital the invalids were dispatched to the Divisions suitable to their varied complaints, the medical cases to the Medical Division, the surgical to the Surgical and those with no special ailments to the Convalescent Division. Never in the history of the hospital was a draft of the same number so quickly dispatched to their wards. They were clothed and fed within an hour of their arrival in the hospital. Next morning the usual bluff came from the Commandant's office beginning "I have been informed ... and requested to be informed why the orderly officer did not attend at the hospital in time to send the invalids to the wards without undue waiting and that they were without food for two hours in consequence".

I was sent for by the Principal Medical Officer and rebuked for allowing this gross irregularity. I repudiated the charge and stated that never was a draft dismissed to the wards with such alacrity and that as the Commandant was present on the verandah he must have known that the report was groundless. The Principal Medical Officer was about to reply to the letter, when I suggested to interview the Commandant. To this he demurred being out of the orthodox mode of procedure. I assured him that it would save him from many such complaints if he allowed me to point out the facts of the case, where I could prove the absurdity of the charge. We went to the Commandant's office and after our explanation he took the letter back from the Principal Medical Officer and tore it into shreds. During Dr. Rowbotham's administration he never interfered again.

About midsummer the new Principal Medical Officer arrived and took over his duties; a veritable "Kerry Bull" whose voice of thunder could make his native hills echo for miles around. He would have made an admirable drill instructor. To offer resistance to his will or to question the wisdom of his actions was to incur extreme displeasure. He was obsequious to his superiors but the reverse to his subordinates. He achieved some laurels by bluff. After the placid " Aberdonian " this "fiery Irishman " was not the happiest selection for an eruptive zone. 
Early one morning, shortly after his arrival, I was summoned into his august presence. In an angry voice he shouted out his question "Why did you turn an officer out of his quarter assigned to him by the Mess Steward?" To this I replied that the mess steward was not authorized to open doors that I had locked, and that the quarter in question was specially assigned to another officer at his own express desire. At this he railed and denied my statement shouting "Don't prevaricate to me". I advanced towards him in anger demanding an apology, telling him that prevarication was not one of my frailities. The officer who made the complaint, medical candidate J. H. Barrett, now made a move for the door. Placing my back to the door, I declined to allow him out until the Principal Medical Officer withdrew his insulting remark. On this he muttered "If I have said anything wrong I am sorry to have said it".

I declined to accept such an apology and informed him that I would submit the matter to His Serene Highness Prince Edward, who would not allow subordinates to be insulted with impunity. Still holding the door I refused to move until he apologised. At last he apologised for his outburst of temper. I then reminded him that the room in question was reserved by his orders for the Medical Officer sent from the Colonial Office for a course of instruction in Hygiene. He then exonerated me ungrudgingly. We understood each other better after this passage of arms.

At the close of the summer session of the Medical School, the Duke of Cambridge accompanied the Director-General to Netley, inspected the Hospital and distributed the prizes. The usual invitations to meet the Duke at lunch were issued, but because of the treatment at the hands of the Mess President at the last breaking up, I declined the invitation. This was reported to the Principal Medical Officer and I was sent for and asked my reason for declining the invitation to the lunch. I gave him my reason, explaining how I had been treated on the last occasion of the breaking up of the school. He remarked that he had heard the Director-General giving me instructions to keep near the Duke and answer questions bearing on the interior economy of the hospital. "What if he misses you from the lunch?" I told him that so long as medical officers treated the officers of the Army Hospital Corps with contumely I would never enter the Mess, adding that I would have what Her Majesty's Commission gave me, equality or nothing. I then left him and returned to my quarters.

I had been there but a few minutes when the Principal Medical Officer was announced. He insisted that I should accompany him, remarking that he had been so recently appointed that he knew nothing of the working of the hospital, and gave me a definite order to meet him there at the appointed hour. I reluctantly obeyed.

The Commandant, Sir Charles K. Pearson, K.C.B. (W.K.M. It seems not unreasonable to mention here that William Morrison was doomed to serve under Sir Charles when he became General-Officer-Commanding the West Indies in 1884, as will appear later in the autobiography) seemed to have cherished an innate dislike to the men of the Army Hospital Corps whenever he could bring home to them any charge to their discredit, he would pursue it to the bitter end. He was particularly severe in the matter of hospital damages, insisted that whatever damages could not be brought home to individuals would be charged to the Army Hospital Corps. To meet damages to buildîngs, loss of stores and breakages by bedridden patients a fund was established at the opening of the hospital by a contribution of one penny a month from every patient in the hospital. 
This fund was allowed to accumulate in the Pay Office year after year, until one of the clerks, a protege of Sir Richard Wilbraham's, an ex-sergeant of the 7th Fusiliers, misappropriated the whole of it and disappeared.

It was from that time paid to the War Office at the end of each financial year. On entering my duties at Netley I assessed damages that could not be traced to individuals against the fund. When this appeared in Garrison Orders, I was summoned into the Commandant's presence and asked how I dared to assess damages against the penny fund without his authority. My answer was the production of the Army Hospital Regulations, arming me with an apparently unconditional prerogative of assessment and until this was cancelled I would carry out my instructions. I told him that I was sent there to carry out the Regulations and not to make a new code. "That" he remarked " accounts for the support you get on references to London. Your predecessor always submitted this to me". I remarked that I never submitted to another any power vested in me by the Regulations of the Service.

Finding that the new Principal Medical Officer was more easily handled than Brigade Surgeon Rowbotham, the Commandant felt that he was on safe ground to apply for a Company of Infantry to be stationed at Netley for general duties on the plea that the Army Hospital Corps could not cope with an outbreak of fire. I was told that the application was made out and only awaited signature. I suggested the prudence of testing whether we were capable or not before sentence of condemnation was carried out. Accordingly one morning sometime after eleven o'clock I was informed by the Principal Medical Officer to parade my men for fire duty at 2 p.m. and that the fire display would be at the sick officers quarters where a fire actually took place two years before. I was not to leave the parade ground until the last chime of the two o'clock stroke.

The Principal Medical Officer was most anxious about this test, knowing that if a combatant officer was stationed at Netley he would preside at the Mess Meetings. I tried to impress on him that we had nothing to lose but a lost reputation to recover. I had personally drilled the whole of the Detachment at Fire Drill every. Friday afternoon for over a year and was prepared to back them against any Fire Brigade in the Country using the same engines as we had. As the last chime of two was struck the command "Left turn, to your stations, double march" set the Detachment in motion. The whole station had turned out to witness the parade.

I declined professional assistance from the Army Service Corps, and from the Discharge Depot. I was anxious to impress on the Commandant that the Royal Victoria Hospital could dispense with help from other units. The only medical officer who rendered me any countenance or assistance was Surgeon Major W. T. Martin, the Hospital Registrar and Medical Officer in charge of the Convalescent Division. I could always look to this officer for guidance and support. In accordance with the Standing Orders of the Hospital the ward orderlies and storemen were in their wards and stores. Only clerks and general fatigue men were taken to work the Fire Engines. In twelve minutes three engines were pouring water on the roof. Half a dozen men had drawn up the hose on to the roof and were directing the water supply.

On seeing this the Commandant turned round and said "You have disappointed me". To this I answered "I hope Sir Charles you did not expect them to reach the roof 
in less than twelve minutes". "No" he replied "If you had taken half-an-hour I would have said that you did well; it took your predecessor two hours to get the water on the building on the actual outbreak of fire eighteen months previously". I had then to explain to him our method of teaching, which gratified him much. The application for the Infantry found its grave in the waste paper basket.

(to be continued)

Representative Colonel Commandant R.A.M.C.

Major-General D. G. Levis, C.B., O.B.E., M.B., D.P.H., has been appointed Representative Colonel Commandant R.A.M.C. for 1975, in succession to Colonel J. A. Brunt.

New Year Honours List 1975

O.B.E. Lieutenant-Colonel P. H. Swinhoe, R.A.M.C. Lieutenant-Colonel D. M. G. Myles, R.A.M.C. (T. \& A.V.R.)

M.B.E. Major (Q.M.) J. C. P. Shannon, R.A.M.C. (T. \& A.V.R.). Captain (N.D.) G. R. Kirsopp, R.A.D.C.

R.R.C. First Class. Lieutenant-Colonel G. R. Dawe, Q.A.R.A.N.C. LieutenantColonel M. J. Fleet, Q.A.R.A.N.C. (T. \& A.V.R.). Retired.

A.R.R.C. Captain M. J. Sloman, Q.A.R.A.N.C. 